\title{
Integrated management approach for the management of pod borer, Helicoverpa armigera (Hubner) on chickpea
}

\author{
UPESH KUMAR*, AJIT KRAPAL SAHU, SANDEEP CHOUHAN AND SURESH CHAND KANTWA \\ Krishi Vigyan Kendra, SEHORE (M.P.) INDIA
}

\section{ARITCLE INFO \\ Received : 25.06 .2016 \\ Accepted : 23.09 .2016}

\section{KEY WORDS :}

Integrated management, Pod borer, Chickpea

*Corresponding author:

\begin{abstract}
An demonstration was conducted to disseminate the IPM approach for the management of pod borer, Helicoverpa armigera (Hubner) in chickpea field. We are demonstrate IPM module - SDP + Optimum seed rate $(75 \mathrm{~kg} / \mathrm{ha})+$ Pheromone trap $(10 / \mathrm{ha})+$ Bird purcher (50/ ha) + inter cropping of mustard (10:1) + One spray of Neem based insecticide at 50 per cent flowering and second spray of Trizophos $40 \mathrm{EC}$ at pod formation stage. The sowing of chickpea crop was II $^{\text {nd }}$ fortnight of October. Under demonstrated technology they reduce the larval population $(44.4 \%)$, reduce the pod damage $(42.49$ $\%)$ resulted enhance the yield $(33.64 \%)$. IPM technology are ecofriedly manage the pod borer, enhance the productivity as well as profitability.

How to view point the article : Kumar, Upesh, Sahu, Ajit Krapal, Chouhan, Sandeep and Kantwa, Suresh Chand (2016). Integrated management approach for the management of pod borer, Helicoverpa armigera (Hubner) on chickpea. Internat. J. Plant Protec., 9(2) : 635-638, DOI : 10.15740/HAS/IJPP/9.2/635-638.
\end{abstract}

